\title{
POJECIE NADZIEI W LISTACH ŚW. AMBROŻEGO Z MEDIOLANU
}

Przebrzmiały już dawno pierwsze echa, pochwały, zachwyty czy krytyki, jakie wywołało ukazanie się nowej encykliki papieża Benedykta XVI na temat nadziei. Jednak temat ten, zawsze bardzo aktualny, nie może być zamknięty po ukazaniu się kilku komentarzy „,na gorąco”. Zasługuje na to, by do niego powracać przez lekturę i osobistą refleksję. Sam fakt, że Ojciec Święty zechciał poświęcić nadziei całą swoją encyklikę, wyraźnie dowodzi, jak temat ten jest aktualny właśnie w naszych czasach. Dodajmy, iż nie jest to bynajmniej jedyny dokument Kościoła poświęcony nadziei w ostatnim czasie: wspomnijmy chociażby Konstytucję soborową o Kościele w świecie współczesnym Gaudium et spes i książkę Jana Pawła II Przekroczyć próg nadziei.

1. Zbawieni w nadziei. Ponieważ Benedykt XVI w swej encyklice nawiązuje też do sytuacji świata w starożytności, zwłaszcza w cesarstwie rzymskim, postanowiłem zbadać, co na temat nadziei mówi w swoich listach jeden z wybitnych mężów Kościoła starożytnego - św. Ambroży z Mediolanu. Jednak ze względu na wymiar tego artykułu ograniczę się do omówienia tylko tych fragmentów, gdzie pojęcie nadziei pojawia się w sposób wyraźny, pozostawiając na przyszłość szczegółowe opracowanie tego tematu.

Od razu na początku uderza zdumiewające podobieństwo między tekstem św. Ambrożego w Liście 22, a tym, co napisał w encyklice Benedykt XVI. Przytoczę zatem obie wypowiedzi, aby można je było porównać. Św. Ambroży pisze:

„Dlatego Apostoł chlubi się mówiąc, że «w nadziei już jesteśmy zbawieni» (Rz 8, 24); nadzieja bowiem zbawia, jak również wiara, o której mówi się: «Twoja wiara cię uzdrowiła» (Łk 18, 42)"'.

Papież zaś mówi zaraz na początku encykliki:

„W nadziei już jesteśmy zbawieni, mówi św. Paweł Rzymianom, a także nam (Rz 8, 24) [...]. «Nadzieja» w istocie jest centralnym słowem wiary biblijnej - do tego

${ }^{1}$ Epistola 22, 33, SAEMO 19, 228, thum. P. Nowak, BOK 9, 177. 
stopnia, że w niektórych tekstach słowa «wiara» i «nadzieja» wydają się być używane zamiennie" 2 .

Znajdujemy także inne podobieństwa; szczególnie to, że obaj obficie czerpią z myśli św. Pawła Apostoła, zwłaszcza wyrażonych w Listach do Rzymian i Efezjan.

Przyjrzyjmy się jednak teraz różnym aspektom nadziei przedstawionym w Listach św. Ambrożego. Rozwijając odniesienie nadziei do wiary w dobra przyszłe, nasz Biskup pisze:

„Zatem «stworzenie», które «zostało poddane marności nie z własnej chęci, ale w nadziei» (Rz 8, 20), przez nadzieję jest zbawione; podobnie jak Paweł, chociaż wiedział, że zyskiem dla niego było umrzeć, aby być z Chrystusem uwolniony od ciała, jednak pozostawał w ciele (por. Flp 1, 21-24) ze względu na tych, których chciał pozyskać dla Chrystusa. Czym zaś jest nadzieja, jeśli nie oczekiwaniem rzeczy przyszłych? Dlatego mówi: „Nadzieja zaś, którą się ogląda, nie jest nadzieją" (Rz 8, 24). Albowiem nie to, co widzialne, lecz to, co niewidzialne, trwa wiecznie (por. 2Kor 4, 18)! Bo «jak można się jeszcze spodziewać tego, co się już ogląda? (Rz 8, 24). Wydaje nam się bowiem, że posiadamy to, co widzimy; jakże więc możemy spodziewać się tego, co posiadamy? Zatem nie widzi się niczego z tego, czego się spodziewa. Bo «ani oko nie widziało, ani ucho nie słyszało, jak wielkie rzeczy przygotował Bóg tym, którzy Go miłują» (1Kor 2, 9)"3.

$\mathrm{Na}$ szczególną uwagę zasługuje komentarz do Listu do Efezjan, zawarty w liście do kapłana Ireneusza; według św. Ambrożego jednym z głównych tematów tego Listu jest właśnie nadzieja. Zaraz na początku tak pisze:

„Apostoł zamierzał przekonać nas, że nie powinniśmy rozpaczać o Królestwie Bożym (por. Ef 3, 12)" ${ }^{4}$.

Kontynuując swoje wywody, podejmuje temat nadziei przedstawionej jako bodziec dla wierzących w zabieganiu o dobra duchowe:

„Przedstawił zatem po pierwsze - co dla dobrych ludzi jest zazwyczaj największą pobudką w dążeniu do cnoty - nadzieję nagród i dziedzictwo niebieskich obietnic""5.

Oczywiście dawcą nadziei, podobnie jak wszystkich innych przyszłych dóbr, jest Chrystus. List, zgodnie z całą teologią św. Ambrożego, jest głęboko chrystocentryczny; dlatego w konsekwencji chrystocentryczna jest jego koncepcja chrześcijańskiej nadziei. Właśnie tu pojawia się bardzo piękne stwierdzenie, będące jakby dojrzałym owocem życia i nauczania tego Doktora Kościoła: "Celem naszej nadziei jest Jego miłość"

\footnotetext{
2 Benedictus XVI, Litterae encyclicae ,Spe salvi” 1-2, wyd. KAI, Warszawa 2007, 3-4.

3 Epistola 22, 14, SAEMO 19, 228-230, BOK 9, 177-178.

4 Epistola 16, 1, SAEMO 19, 158, BOK 9, 131.

5 Epistola 16, 2, SAEMO 19, 160, BOK 9, 131.

6 Epistola 16, 3, SAEMO 19, 160, BOK 9, 131.
} 
Chrystocentryczne ujęcie koncepcji nadziei pojawia się także w zakończeniu listu 22, adresowanego do Oroncjana. Na kanwie rozważania tekstów św. Pawła z Listu do Rzymian nasz Autor z jednej strony pokazuje, że nie dają żadnej nadziei potęga, wiedza i bogactwo, aby z drugiej strony uświadomić nam, gdzie możemy ją naprawdę znaleźć:

„Pięknie zatem mówi się: «Nadzieja zaś, którą się ogląda, nie jest nadzieją» (Rz 8, 24), odnośnie władz tego świata, godności, bogactw [...]. Nie ma żadnej nadziei w rydwanach, które się widzi. Ani nawet nie ma nadziei w samych elementach nieba, lecz tylko w Panu nieba; ani Chaldejczyk nie ma nadziei w gwiazdach, które obserwuje, ani bogacz w swoich posiadłościach, ani chciwiec w lichwie. Lecz ma nadzieję ten, kto swoją nadzieję pokłada w Tym, którego nie widzi, to jest w Panu Jezusie" "7.

Podobnie w zakończeniu listu 31, skierowanego do tego samego adresata, nadzieja jest ściśle związana z osobą Chrystusa, stojącego w centrum całego świata:

„On jest nowym Kapłanem i nową Ofiarą, nie na podstawie Prawa, lecz ponad Prawem; Adwokat świata, «światłość świata» (J 8, 12), który powiedział: «Oto przychodzę» (por. Ap 22, 7). I przyszedł, abyśmy się przybliżyli do Niego «z wiarą pełną» (Hbr 10,22), adorując Go, błagając i pokładając nadzieję w Nim, «którego nie widzieliśmy naszymi oczami, lecz obejmujemy Go naszym uczuciem» (por. 1P 1,8$)$, do Niego należy zawsze wszelka cześć i chwała"8.

2. Nadzieja i cierpienia. Nawiązując do Listu św. Pawła Apostoła do Rzymian, ukazuje nadzieję w relacji z cierpieniem i krzyżem. Rozważając w liście do Ireneusza postawę patriarchy Jakuba, w którym widzi typ Chrystusa, kończy swoje wywody zachętą do przyjmowania krzyża:

„Idźmy więc za świętym Jakubem jego drogami, abyśmy doszli do tych cierpień, do tego zmagania [...]. Gdzie jest wytrwałość, tam jest wesele, ponieważ ucisk wyrabia wytrwałość, a wytrwałość - wypróbowaną cnotę, w której jest nadzieja, która zawieść nie może (por. Rz 5, 3-5), bo kto się nie powstydzi krzyża Chrystusa, tego i Chrystus wstydzić się nie będzie (por. Mk 8, 38)"'.

Do duszy cierpiącej, porównanej do rodzącej kobiety, stosuje słowa Apostoła: „Albowiem bóle rodzącej (por. Mi 4,10) powodują ucisk, «ucisk wyrabia wytrwałość, a wytrwałość - wypróbowaną cnotę, wypróbowana cnota zaś - nadzieję» ( Rz 5, 3-4), a nadzieja nie zawodzi (por. Rz 5,4) na wieki (por. Ps 71, 1)"10.

\footnotetext{
7 Epistola 22, 16, SAEMO 19, 230-232, BOK 9, 178-179.

8 Epistola 31, 19, SAEMO 19, 310, BOK 9, 237.

9 Epistola 4, 17, SAEMO 19, 58-60, BOK 9, 56.

10 Epistola 18, 6, SAEMO 19, 182, BOK 9, 147.
} 
Mówiąc dalej o sprawiedliwych znoszących pokusy i utrapienia, pisze:

„,«We wszystkim tym odnosimy pełne zwycięstwo dzięki Temu, który nas umiłował» (Rz 8, 37), ponieważ $\mathrm{w}$ Nim pokładamy nadzieję, że ani śmierć, ani jakakolwiek z pokus nie może nas wyrwać ani odłączyć od Jego miłości (por. Rz 8, 38-39)"11.

Do cierpień i prześladowań, jakich doznawali święci, nasz Autor powraca pod koniec życia w liście do wiernych Kościoła w Vercelli, gdy zwalcza błędne nauki hedonistyczne szerzone wśród nich przez dwóch eks-mnichów, wydalonych z jego wspólnoty w Mediolanie, broniąc jednocześnie wzniosłej wartości postu, ofiary życia w dziewictwie lub czystości. Pokazuje przy tym wyraźnie, że - podobnie jak pogańscy zwolennicy Epikura - oni nie mają żadnej nadziei przyszłego życia:

„Kimże są więc ci nowi nauczyciele, którzy wykluczają zasługę postu? Czyż nie jest to głos pogan mówiących: «Jedzmy i pijmy» (Iz 22, 13)? Słusznie wyśmiewa ich Apostoł, mówiąc: «Jeżeli tylko ze względu na ludzi potykałem się w Efezie z dzikimi zwierzętami, to cóż mi stąd za pożytek? Skoro zmarli nie zmartwychwstają, to jedzmy i pijmy, bo jutro pomrzemy» (1Kor 15, 32), to znaczy: jaki był dla mnie pożytek ze zmagania się aż do śmierci, jeśli nie odkupienie człowieka, który jest we mnie? Gdyż na próżno jest odkupiony, jeśli nie ma żadnej nadziei zmartwychwstania. I przez to, straciwszy wszelką nadzieję odkupienia, «jedzmy i pijmy»; nie traćmy używania dóbr doczesnych, skoro nie mamy żadnego [pożytku z] dóbr przyszłych. Ci przeto oddają się pilnie używaniu pokarmów i napojów, którzy nie spodziewają się niczego po swej śmierci"12.

Przeciwstawia im słabe fizycznie, lecz wzmocnione wiarą i ascezą niewiasty: „Judyta, żadną miarą nie skuszona hulaszczą ucztą Holofernesa, jedynie za pomocą trzeźwości odniosła triumf [...]. Ester wyniosłego króla skłoniła swoimi postami (por. Est 4, 16-7, 10). Anna, mająca osiemdziesiąt cztery lata, dniem i nocą służąc Bogu w świątyni w czasie swego wdowieństwa przez posty i modlitwy, poznała Chrystusa (por. Łk 2, 37-38), którego Jan, nauczyciel abstynencji, jakby jakiś nowy anioł na ziemi, zwiastował (por. Mt 3, 4. 11)"13.

Następnie odwołuje się do przykładów znanych, wybitnych postaci proroków:

„Stąd wyszli tacy mężowie, jak Eliasz, Elizeusz, Jan, syn Elżbiety, którzy przyodziani w szaty ze skór i w okrycia z koziej skóry (por. $2 \mathrm{Krl} 1,8$; Mk 1, 6), cierpiąc biedę i niedostatek, znosząc ucisk i cierpienia, błąkali się po pustyniach (por. $1 \mathrm{Krl}$ 19, 4; Mt 3, 1; Łk 3,2), wśród szczytów i lasem pokrytych gór, po niedostępnych skałach, dzikich jaskiniach, płytkich rozpadlinach, gdyż świat nie był wart obcowania z nimi (por. Hbr 11, 37-38). Stąd ci [młodzieńcy], jak Daniel, Ananiasz,

11 Epistola 18, 17, SAEMO 19, 188, BOK 9, 151-152.

12 Epistola 14*, 17, SAEMO 21, 271 (tu i w dalszych przypisach gwiazdką oznaczono Epistulae extra collectionem).

13 Tamże 29, SAEMO 21, 278. 
Azariasz i Miszael, którzy mieli [przydzielone] wyżywienie w pałacu królewskim, żywili się poszcząc jak na pustyni, mając prosty pokarm i zwyczajny napój (por. Dn 1, 6-16); i słusznie ci słudzy królewscy mieli przewagę nad królestwami i wzgardzili niewolą, zrzuciwszy jej jarzmo, podporządkowali sobie potęgi, pokonali elementy, zgasili [palącą] naturę ognia, uczynili nieszkodliwymi płomienie, stępili ostrze miecza, zamknęli paszcze lwów, i gdzie uważano ich za słabszych, tam spostrzegano, że są mocniejsi. Nie unikali wyszydzenia przez ludzi, ponieważ spodziewali się nagród niebiańskich; nie przerażały ich mroki lochu, poniewaź świeciła im łaska światłości wiekuistej”,14.

W końcu przechodzi do przypomnienia świadectwa świętych biskupów, którzy za swą wierność Bogu i katolickiej nauce zostali skazani na wygnanie i poniewierkę (a byli wśród nich jego poprzednik na stolicy biskupiej w Mediolanie św. Dionizy oraz św. Euzebiusz, biskup Vercelli): ich motywacją zaś dla chętnego przyjmowania tych cierpień była nadzieja przyszłego życia:
„Nie pragnęli mieć grobu w ojczyźnie ci, dla których było przygotowane niebieskie mieszkanie. Błąkali się po całym świecie «jako ci, którzy nic nie mają, a posiadają wszystko» (2Kor 6,10). Dokądkolwiek by nie zostali zesłani, uważali to za miejsce rozkoszy; bo niczego nie brakowało tym, którzy obfitowali w bogactwo wiary. Dlatego sami będąc biedni w środki do życia, wzbogacali innych (por. 2Kor 6 , 10), ponieważ byli obficie wyposażeni w łaskę. Byli wystawiani na próbę, lecz nie wydawani na śmierć w postach, trudach, więzieniach, czuwaniach (por. 2Kor 11 , 27). Ze swej słabości wychodzili mocni (por. Hbr 11, 34). Nie oczekiwali ponęt rozkoszy, gdyż utuczył ich głód; nie paliło ich gorące lato, ponieważ chłodziła ich nadzieja wiekuistej łaski; nie złamały ich mrozy lodowatej krainy, ponieważ dzięki żarliwości ducha dla nich rozkwitała wiosenna pobożność; nie lękali się kajdan ludzi, ponieważ Jezus ich uwolnił; nie pragnęli być wybawieni od śmierci, ponieważ spodziewali się, że zostaną wskrzeszeni przez Chrystusa" ${ }^{15}$.

Wreszcie, jakby na zakończenie zachęt ascetycznych, podkreśla pilną potrzebę poskramiania pożądań duchowych, ograniczając się do tego, co ściśle konieczne:

„Czemuż to szukacie, jakby czegoś koniecznego, ogromu bogactw? Nic nie jest tak konieczne, jak poznanie, co nie jest konieczne. Czemu wykręcacie się, usprawiedliwiając się ciałem? To nie brzuch cielesny czyni [człowieka] nienasyconym, lecz żądza ducha. Czyż to ciało zabrało wam nadzieję na przyszłość? Czy to ciało wydarło wam słodycz duchowej łaski ${ }^{16}$ "?

W czasie Wielkiego Tygodnia 386 r., kiedy katolicy w Mediolanie razem ze swoim Pasterzem w dzień i w nocy okupowali kościoły, aby nie zostały im zabrane przez arian i sprzyjającego im cesarza Walentyniana II, w homilii do

\footnotetext{
14 Tamże 67, SAEMO 21, 296.

15 Tamże 69, SAEMO 21, 298.

16 Tamże 91, SAEMO 21, 308-310.
} 
tekstu z Księgi Hioba św. Ambroży - jak sam to opisuje swej siostrze Marcelinie - tak powiedział:

„To wypada chrześcijanom: pragnąć spokojnego pokoju, lecz nie powstrzymać się od stałości wiary i prawdy nawet w niebezpieczeństwie śmierci. Bo Pan jest [naszym] obrońcą, który zbawi tych, co w Nim pokładają nadzieję (por. Ps 17, 7)"17.

Następnego dnia, dodając znowu wiernym otuchy, komentuje Księgę Jonasza:

„[Słuchający] przyjęli to jak ci, którzy w obecnym czasie mają nadzieję na przyszłość" 18 .

Pięknym przykładem nadziei, będącej źródłem odwagi dla wierzących w Pana, jest świadectwo naszego Biskupa, zawarte w jego liście do uzurpatora Eugeniusza, któremu wyjaśnia, dlaczego nie chciał się z nim spotkać i wyjechał z Mediolanu:

„Nie zwykłem nigdy względów jakiegokolwiek człowieka cenić bardziej, niż łaski Chrystusa. Nikogo bowiem nie obrażam, jeśli przedkładam ponad wszystkich Boga i, w Nim pokładając nadzieję, nie boję się wam, władcom, mówić tego, co czuję [...]. Dlatego także wobec ciebie, najłaskawszy cesarzu, nie przemilczę tego, czego nie przemilczałem wobec innych cesarzy"19.

Temat nadziei na tle cierpienia pojawia się nie tylko w odniesieniu do ludzi, ale również do całego stworzenia. W liście 21 do Oroncjana, wielokrotnie powraca myśl z Rz 8, 20, że stworzenie zostało poddane marności - w nadziei, wyjaśniana i aplikowana na różne sposoby przez św. Ambrożego, który kończy cały ten list takim wnioskiem:

„Jeśli więc także stworzenia i potęgi niebieskie znoszą «niewolę zepsucia» (por. Rz 8,21), lecz w nadziei ( Rz 8,20), aby później dla nas i z nami się radować, także my pocieszajmy się w obecnych cierpieniach (por. Rz 8,18 ) nadzieją i oczekiwaniem przyszłej chwały" ${ }^{\prime 20}$.

Wątek nadziei zawarty w Rz 8, 20 powraca także w innym liście do Oroncjana, gdzie nasz Autor przedstawia człowieka jako zapaśnika na oczach całego stworzenia, walczącego przeciw złym duchom w zawodach o nagrody przygotowane przez Boga:

„Nagrodami przeto dla człowieka są owoce ziemi i światła nieba (por. Rdz 1, 14-

25): tamte dla potrzeb obecnego życia, te dla nadziei życia wiecznego" ${ }^{21}$.

\footnotetext{
17 Epistola 76, 14, SAEMO 21, 144.

18 Tamże 25, SAEMO 21, 150.

19 Epistola 10*, 1, SAEMO 21, 224.

20 Epistola 21, 11, SAEMO 19, 220, BOK 9, 171.

21 Epistola 29, 4, SAEMO 19, 272, BOK 9, 211.
} 
Szczególnym rodzajem cierpienia są pokusy, potęgowane nieraz samotnością. Niekiedy dotkliwie doświadczają go właśnie ci, którzy sami wybrali samotność ze względu na Boga i Jego służbę. Do duchownych, nieraz zniechęconych i kuszonych, by porzucić swą służbę i opuścić swe miejsce w Kościele (jakież to aktualne!), nasz Biskup pisze te słowa:

„Nieprzyjaciel pragnie ci je wydrzeć, chce cię od niego odwieść, gdyż zazdrości ci twojej nadziei, zazdrości ci twojej służby"22.

Ciekawy aspekt nadziei jest ukazany zaraz w pierwszym liście: komentując wypowiedź Wj 12, 4 (przepis dotyczący spożywania Paschy), nasz Biskup odnosi go do Eucharystii, z konkretną troską duszpasterską, związaną z ilością uczestników - aby czasem ktoś z tego powodu nie był pozbawiony pokarmu Ciała Chrystusa:

„Nie powinno być za dużo osób, aby ktoś nie odszedł pozbawiony nadziei i zbawienia" ${ }^{23}$.

3. Nadzieja a inne cnoty lub wady. Już na początku artykułu zaznaczyłem związek nadziei z wiarą, podkreślony zarówno przez papieża Benedykta, jak też przez naszego Autora. Kilka razy św. Ambroży łączy ściśle ze sobą w jedno wszystkie trzy cnoty teologalne, zwłaszcza komentując listy Pawłowe. I tak w kolejnym liście do Oroncjana pisze:

„Jednakże nie powiedziałbym tak łatwo, że od razu wszelka wiara ma doskonałą miłość, ponieważ Apostoł powiedział: «Gdybym posiadał wszelką wiarę, tak iżbym góry przenosił, a miłości bym nie miał, nic bym nie zyskał» (1 Kor 13, 2. 3). Bo chociaż u chrześcijanina głównie są trzy [cnoty]: «nadzieja, wiara, miłość», to «największa z nich jest miłość» (1Kor 13, 13)" ${ }^{\text {24 }}$.

Następnie kontynuuje swe rozważania w tym samym liście, aby w zakończeniu tak podsumować swój wykład:

„Myślę, że dlatego jest powiedziane, iż «miłość wszystkiemu wierzy» (1 Kor 13, 7), to znaczy sprawia, że wiara we wszystko wierzy i tak [przygotowana] dusza ma «wszelką wiarę» (1Kor 13,2). I przez to gdzie jest doskonała miłość, tam jest wszelka wiara, podobnie jak tam, gdzie jest doskonała miłość, jest wszelka nadzieja. Dlatego jak «wszystkiemu wierzy», tak jest napisane, ze «we wszystkim pokłada nadzieję» (1Kor 13, 7). Z tego powodu [miłość] jest największa, gdyż obejmuje nadzieję i wiarę (por. 1Kor 13,13). Kto ma taką miłość, niczego się nie boi, ponieważ «miłość usuwa lęk» (1J 4,18), i dlatego, oddaliwszy i wyzbywszy się lęku, «wszystko znosi, wszystko przetrzyma» (1Kor 13, 7). Kto zatem przez

22 Epistola 17, 13, SAEMO 19, 176, BOK 9, 142.

${ }^{23}$ Epistola 1, 9, SAEMO 19, 26, BOK 9, 33

${ }^{24}$ Epistola 66, 6, SAEMO 20, 186, BOK 9, 126. 
miłość wszystko przetrzyma, nie może lękać się męczeństwa. I dlatego - jak zwycięzca - na innym miejscu w końcu [listu Apostoł] mówi: «Świat stał się ukrzyżowany dla mnie, a ja dla świata» (Ga 6,14). Bądź zdrów, synu, i kochaj nas, gdyż i my cię kochamy"25.

W liście do cesarza Gracjana św. Ambroży - chociaż po ojcowsku napomina go za pewne błędne teorie - zawarł piękne zdanie wyrażające bliski związek nadziei z miłością do Boga:

„Od Ojca spodziewasz się nagrody za miłość do Syna"26.

Jednym z zadań biskupa jest wykorzeniać wady ludu i zachęcać go do cnót. Mówiąc o różnych wadach, św. Ambroży pisze:

„To są ciężkie choroby duszy, które ją często doprowadzają do śmierci, podczas gdy jej oczy są oślepione" ${ }^{27}$.

Dlatego dalej zachęca:

„Natomiast jeśli będzie zawsze zwracać je ku Bogu, otrzyma od Chrystusa blask mądrości, aby miała wzrok oświecony w poznaniu Boga, aby widziała tę nadzieję naszego powołania (por. Ef 1, 17-18) i dostrzegała to, co dobre i prawe (Pwt 12, 28), i doskonałe" ${ }^{\mathrm{2}}$.

Podobnie w liście do nowo wyświęconego biskupa Konstancjusza przyrównuje do nierządnicy różne wady, zwłaszcza lichwiarski wyzysk bliźniego:

„Niewielki zysk z wynagrodzenia nierządnicy (por. Prz 6, 26), to jest tej niebezpiecznej skłonności. Nierządnica ta nie jest wyjątkowa, lecz powszechna; wszelka zmienna pożądliwość jest nie jakąś [normalną] kobietą, lecz nierządnicą. Wszelkie wiarołomstwo, wszelki podstęp jest nierządnicą, nie tylko ta, która oddaje nierządowi swoje ciało, lecz każda dusza, która sprzedaje swoją nadzieję, która szuka haniebnych zysków i niegodziwej korzyści" ${ }^{29}$.

Trochę dalej, w tymże liście, nawiązuje do obrazu wagi, na której są ważone nasze zasługi i grzechy. Dlatego poucza biskupa, żeby zachęcał ludzi do spełniania dobrych uczynków:

„Nikt nie jest wolny od grzechów; lecz gdzie przeważa dobro, grzechy [na szali] się podnoszą, usuwają się do cienia, są zakrywane. Przeto w dniu sądu nasze uczynki albo przyjdą nam z pomocą albo nas pogrą̨żą w otchłani, jakby ściąganych w dół kamieniem młyńskim (por. Mt 18,6). Ciężka jest bowiem nieprawość, obciążona

25 Tamże 9-10, SAEMO 20, 188, BOK 20, 127.

26 Epistola 12*, 5, SAEMO 21, 244.

27 Epistola 11, 16, SAEMO 19, 124, BOK 9, 105.

28 Tamże.

29 Epistola 36, 12, SAEMO 20, 28, BOK 20, 11. 
mianowicie masą ołowiu, nieznośna chciwość i wszelka pycha, wstrętne oszustwo. I dlatego zachęcaj lud Pana, aby bardziej pokładał nadzieję w Panu" ${ }^{30}$.

Również w innym liście, porównując wady i cnoty, wspomina o nadziei: „Szybka jest nieprawość, która podsuwa okazję do szkodzenia, gdyż są jej «nogi szybkie do rozlewu krwi» ( Rz 3,9), każda zaś cnota jest powolna i długo zwleka, zanim coś postanowi i rozpocznie jakieś przedsięwzięcie [...]. Opieszała przeto i wstydliwa jest skrucha, gdyz thumi ją i powstrzymuje wstyd rzeczy obecnych; albowiem zmierza ona jedynie do rzeczy przyszłych, których nadzieja jest odległa, a jeszcze późniejszy owoc, i dlatego powolniejsze jest też samo dążenie do nich. Wśród tych wysiłków nadziei i cnoty wyprzedza je bezwstydność"31.

Natomiast w liście do wiernych w Vercelli, zachęcając ich do naśladowania cnót Świętych, gani opieszałość i bezczynność:

„Widzicie, synowie, kim stali się ci, którzy poszli za tymi [dobrami], jak działają po śmierci. Starajmy się pilnie zdobywać te cnoty, których sławę podziwiamy [...]. Pospieszna jest wiara, ochocza pobożność, pilna nadzieja; nie lubi sprzeciwów, lecz przechodzenie od bezowocnej bezczynności do owocu wysiłków. Czemu odkładasz do jutra? Możesz wykorzystać także dzień dzisiejszy; musisz bowiem strzec się, byś i tamtego nie zmarnował i tego nie stracił. Niemała to rzecz stracić choćby jedną godzinę, bo także jedna godzina jest częścią całego życia"32.

Oczywiście taka postawa, zwłaszcza trwanie w niej przez lata, wymaga stałego wysiłku woli i mądrej ascezy. Jako doświadczony mistrz takiego życia, podczas gdy poucza, że każdy powinien akceptować swój wiek i stan, św. Ambroży mówi:

„I młodzi mogą okazać się dojrzałymi przez swoje obyczaje i starzy mogą być młodymi przez swoje czyny. Albowiem to dyscyplina, bardziej niz wiek, przynosi poprawę obyczajów. Zatem o ileż bardziej powinniśmy wznosić nadzieję do Królestwa Bożego, gdzie będzie nowe życie, gdzie dokona się przemiana łaski, a nie wieku!"33.

4. Nadzieja ludzkiej sprawiedliwości. Pisząc do swego przyjaciela konsula Tacjana, św. Ambroży zachęca go, by w sposób łaskawy rozstrzygnął spór rodzinny ze swoją siostrzenicą i jej ojcem:

„Dlatego przyśpiesz to rozstrzygnięcie, którego i nadzieja jest większa i owoc”."34.

\footnotetext{
30 Tamże 16, SAEMO 20, 32, BOK 20, 13.

31 Epistola 3, 5-6, SAEMO 19, 44-46, BOK 9, 46.

32 Epistola 14*, 97, SAEMO 21, 312.

33 Tamże 98, SAEMO 21, 314.

34 Epistola 45, 2, SAEMO 20, 70, BOK 20, 35.
} 
W roku 386, w bardzo delikatnym momencie, po tym, jak uzurpator Maksym kazał ściąć Pryscyliana za herezję (pomimo interwencji św. Marcina z Tours), nasz Biskup pisze do Studiusza, wysokiego urzędnika rzymskiego i sędziego, w którym zachęca go mocno - odwołując się do przykładu Jezusa w Ewangelii (J 8,1-11) - do miłosierdzia przy wydawaniu wyroków, zwłaszcza do unikania kary śmierci, której stosowaniu św. Ambroży był przeciwny. Przy okazji wyraża nadzieję na poprawę i nawrócenie złoczyńcy:

„Masz przykład do naśladowania. Może bowiem się zdarzyć, że ów przestępca mógłby mieć nadzieję poprawienia się: jeśli nie jest ochrzczony, aby mógł otrzymać odpuszczenie; jeśli jest ochrzczony, aby czynił pokutę i swe ciało złożył w ofierze dla Chrystusa. Jak wiele jest dróg do zbawienia!"35.

Będąc bardzo surowym względem tych, którzy pomówieniami wobec biskupa Werony Syagriusza narazili na szkodę dobre imię dziewicy konsekrowanej Indycji, nasz Biskup - który wziął tę sprawę w swoje ręce i stanął w jej obronie - jednak nie pozbawił winowajców nadziei na otrzymanie przebaczenia:

„Pod wpływem tych zeznań orzekliśmy, że Indycja jest dziewicą o nieposzlakowanej czci. Maksym zaś, Renat i Leoncjusz otrzymali następujący wyrok: Maksymowi - jeśli naprawi swój błąd - zostawia się nadzieję powrotu [do wspólnoty kościelnej], natomiast Renat i Leoncjusz pozostaną objęci ekskomuniką, chyba że przez swoją szczerą skruchę i długotrwałe opłakiwanie tego czynu okażą się godni zmiłowania" 36 .

Po wydaniu tego wyroku pisze jeszcze drugi list do biskupa Syagriusza, w którym go surowo upomina za nieroztropność, a jednocześnie zachęca do stanowczej obrony czystości, dając jako wzór biblijny wojnę jedenastu pokoleń Izraela przeciw Gibeanitom, obszernie opisaną w Księdze Sędziów 19-20. W liście, który jest pięknym przykładem stawania przez niego w obronie poniżanych, gwałconych czy znieważanych kobiet, na marginesie pojawia się też pojęcie nadziei.

„Nagle otoczyli ich Gibeanici, młodzieńcy oddani wszelkiej rozpuście, nie mający nic z rozwagi czy umiarkowania, których uroda kobiety uwiodła i doprowadziła do zupełnego szaleństwa. Zniewoleni bowiem jej pięknością i spodziewając się [łatwo] osiągnąć cel z powodu starości gościa i słabej pomocy, [na jaką mógł liczyć], domagają się kobiety i stukają do bramy [...]. Tak więc, gdy na nic się nie zdały pobożne prośby i gość na próżno wyciągał starcze ręce, bez nadziei na jakąś pomoc, kobieta została porwana i przez całą noc poddana znieważaniu"37.

35 Epistola 50, 8, SAEMO 20, 84, BOK 20, 44.

36 Epistola 56, 24, SAEMO 20, 124, BOK 20, 80.

37 Epistola 57, 7 i 9, SAEMO 20, 130, BOK 20, 83-84. 
Opierając się w dużej mierze na opisie przekazanym przez Józefa Flawiusza, św. Ambroży przedstawia przebieg wojny pozostałych pokoleń Izraela przeciw Beniaminitom, którzy nie chcieli wydać winowajców, aby ponieśli słuszną karę. $\mathrm{Na}$ początku szczęście sprzyjało nieprawym, tak iż Izraelici ponieśli poważne straty:

„I mimo że los im nie sprzyjał i przegrali już dwie bitwy, to jednak Izrael, stanowczy w duchu, żadną miarą nie stracił ufności w zwycięstwo i zrodzonej wcześniej nadziei na dokonanie zemsty. Lecz ponieważ - choć przewyższali [przeciwnika] sprawą i liczbą - gdy doszło do bitwy, okazali się słabsi i musieli się wycofać, byli przekonani, że Bóg jest na nich zagniewany, i postem i wielkim płaczem starali się o zjednanie niebiańskiej łaskawości. Tak więc, po uproszeniu pokoju Pana, bardziej zawzięci wracają do wojny, jako że Boża wyrocznia dodała im odwagi i zwiększyła ich nadzieję (por. Sdz 20, 13-28)"38.

5. Zwodnicze nadzieje. Mówiąc o ludziach skalanych nieprawością, odnosi do nich tekst Księgi Hioba 6, 19-21 i tak pisze:

„O nich mówi Hiob: zobaczcie drogi Temanitów i Sabejczyków, gdyż doznają zawstydzenia ci, którzy pokładają nadzieję w miastach warownych i w bogactwach"

Pisząc do Chromacjusza, rozważa temat grzechu proroka Balaama, czerpiąc myśli z dzieła Filona z Aleksandrii. W długiej wypowiedzi, włożonej w usta Balaama i skierowanej do Balaka, króla Moabu, pisze między innymi tak o cielesnej nadziei:

„Czasem jednak także wierne dusze upadają wobec powabu ciała i ponęty piękności. Masz bardzo wiele kobiet, a większość z nich niebrzydka pod względem urody. Płeć zaś męska, niczemu łatwiej nie ulegająca niż kobiecej piękności, szybko się usidla, szczególnie, gdy namiętność umysłów jest rozpalana częstymi zachętami i zapala się jakby od płonących pochodni, jeśli upaja się nadzieją osiągnięcia swego celu, a odwleka zaspokojenie swej namiętności"

W liście do Ireneusza, tak samo inspirując się na pismach Filona z Aleksandrii, nasz Autor wkłada w usta patriarchy Jakuba stanowcze słowa skierowane do Labana, jego teścia, będącego jakby personifikacją głupoty i różnych wad, od którego Jakub uciekał, m.in. mówi:

„Lecz może miałem nadzieję, że dasz mi na usługi twoich niewolników? Ja jednak szukam wolnych, uciekam od niewolników grzechu" ${ }^{41}$.

38 Tamże 11-12, SAEMO 20, 132, BOK 20, 85; por. tenże, De officiis ministrorum III 19, 112 117; Josephus Flavius, Antiquitates Judaicae V 2, 8-12.

39 Epistola 6, 3, SAEMO 19, 66, BOK 9, 61.

40 Epistola 28, 13, SAEMO 19, 268, BOK 9, 207; por. Philo Alexandrinus, Vita Moysis I 48-53, 267-298.

${ }^{41}$ Epistola 4, 14, SAEMO 19, 58, BOK 9, 55; por. Philo Alexandrinus, De fuga et inventione; tenże, Legum allegoriae. 
Do idących za zwodniczą nadzieją nasz Biskup zalicza tych wszystkich, którzy nie przyjmują Chrystusa. I tak, w nawiązaniu do słów Jezusa w Ewangelii, św. Ambroży podkreśla mocno, że Chrystus jest jedynym Zbawicielem, tzn. jedynym, w którym wszyscy powinni pokładać nadzieję. W tym kontekście stanowczo ukazuje wielki błąd Żydów, którzy odrzucili Jezusa jako Odkupiciela:

„Mojżesz was oskarża, obwinia was ten, «w którym wy pokładacie nadzieję» (J 5, 45); on was oskarża, gdyż nie ma władzy sądzenia, która przysługuje tylko jego Stwórcy. Tamten więc, «w którym wy pokładacie nadzieję», (J 5, 45), was oskarża, Ten zaś, w którym nie chcieliście złożyć nadziei, was uwalnia. O wielka roztropności Żydów! Słusznie są oskarżani za swoje przestępstwa, gdyż wybrali oskarżyciela, a odrzucili dobrego Sędziego. I dlatego nie ma dla nich odpuszczenia, a jest kara" ${ }^{42}$.

Podobnie w innym miejscu, komentując tekst Iz 20, 1-6, św. Ambroży ukazuje odstępstwo od wiary i jego skutki na przykładzie narodu wybranego:

„Żydzi, opuszczeni przez Boga z powodu swoich haniebnych czynów, zaczynali ulegać swoim wrogom; chcieli przyłączyć się do Egipcjan, aby oni byli dla nich obroną przeciw Asyryjczykom, tymczasem powinni byli raczej powrócić do wiary, jeśliby się dobrze zastanowili. Rozgniewany Pan ukazuje im, że żywili próżną nadzieję, gdyż wierzyli, że należy usunąć obrazę Boga za pomocą jeszcze większego grzechu; gdy tymczasem ci, w których pomocy naród żydowski pokładał nadzieję, sami mieli zostać pokonani”,43.

Ludzi żyjących bez wiary w Chrystusa porównuje do snu, a ich dążenia - do marzeń sennych:

„Snem jest ten rodzaj życia, w którym różne zmiany następują po sobie jak pijane, i nie widząc nic pewnego ani stałego - jakby to był sen śpiącego - [w rzeczywistości] nie widzimy, i słysząc nie słyszymy, i jedząc nie sycimy się, radując się nie doznajemy radości, biegnąc nie osiągamy celu. Próżne są nadzieje ludzi na tym świecie, gdyż sądzą, że powinni iść za rzeczami, które nie istnieją, tak jakby istniały. Dlatego tak jak we śnie próżne i czcze obrazy rzeczy przychodzą i odchodzą, są i znikają, roztaczają się i rozpraszają, zdaje się, że da się je uchwycić, a nie chwyta się ich. Dlatego gdy ktoś usłyszał mówiącego: «zbudź się, o śpiący» (Ef 5, 14), i powstał ze snu tego świata, zrozumiał, że wszystkie te rzeczy są złudne; zbudził się i zniknął sen, zniknęła władza, minęła troska o dziedzictwo, piękność wyglądu, gorliwe dążenie do stanowisk. To są bowiem sny, którymi nie są poruszani ludzie o czuwającym sercu, natomiast dręczą one śpiących" ${ }^{\text {"4 }}$.

Innego rodzaju fałszywe nadzieje żywili poganie, starający się o przywrócenie w senacie rzymskim ołtarza i kultu bogini Wiktorii. Delegacja pogańskich

42 Epistola 20, 13-14, SAEMO 19, 210, BOK 9, 166.

43 Epistola 27, 15-16, SAEMO 19, 258-260, BOK 9, 201-202.

44 Epistola 36, 22, SAEMO 20, 34-36, BOK 20, 15-16. 
senatorów dwukrotnie starała się uzyskać ten przywilej u cesarza Walentyniana II, jednak zdecydowana i mądra interwencja św. Ambrożego przeszkodziła temu skutecznie. W liście do cesarza pisze on m.in.:

„Skoro więc ty, bardzo chrześcijański cesarzu, masz okazać swą wiarę w prawdziwego Boga, a także gorliwość o tę wiarę, roztropność i pobożność, dziwię się temu, jak niektórzy mogli mieć nadzieję, że powinieneś twoim rozkazem postawić na nowo ołtarze bogom pogańskim, a także dostarczyć środków na użytek pogańskich ofiar" ${ }^{\prime 4}$.

Stojący na czele delegacji senator Symmach przedstawił cesarzowi relację, w której m.in. mówi o nieurodzajach, jakie wówczas nawiedziły cesarstwo; oczywiście przyczyn tego doszukuje się w krzywdach wyrządzonych dawnej religii Rzymian:

„Niech nikt nie myśli, że bronię tylko sprawy religii; z takich występków wzięły się wszystkie nieszczęścia ludu rzymskiego. Prawo ojców uczciło dziewice westalki i sługi bogów poprzez skromne utrzymanie i słuszne przywileje. Ten dar pozostał nienaruszony aż do czasu, gdy niegodziwi bankierzy środki utrzymania świętej czystości przeznaczyli na wynagrodzenie dla nędznych grabarzy. Po tym fakcie przyszedł powszechny głód i choroba zbóż, które zawiodły nadzieję wszystkich prowincji [na dobre zbiory]"

Nasz Biskup nie omieszkał odpowiedzieć na stawiane zarzuty, wykazując, jak są tendencyjne i nieprawdziwe, a przy okazji wykpił również samą religię pogańską:

„Tak naprawdę [działo się to też] dawniej, kiedy obsiane pole pustymi kłosami zawodziło pragnienia żądnego [plonu] rolnika, a nadzieję wiejskiej ludności oszukiwały zielone źdźbła zbóż, których [na próżno] szukali na zagonach [...]. Jaka to sprawiedliwość, by bolejąc z powodu odmówienia żywności nielicznym kapłanom, bogowie odmawiali jej wszystkim, przez co bardziej bezwzględna była kara niż wina? Nie to zatem jest przyczyną zdolną ściągnąc tak wielkie utrapienie zwodniczego świata, by nagle, gdy obsiane pola już się zazieleniły, zginęła nadzieja na roczny [zbiór już] wyrośnięty" ${ }^{\prime 4}$.

Odwołując się do najwyższego autorytetu władzy cesarskiej przeciw zakusom Ursyna, który usiłował za wszelką cenę usunąć św. Damazego I i zdobyć dla siebie urząd papieski, angażując w to heretyków i rzezimieszków, nasz Biskup tak pisze:

„Potępiony wiele razy z powodu [wywołanych] zamieszek, jednak znowu wystąpił, [...] połączył się i związał z arianami w owym czasie, w którym razem z Walensem

45 Epistola 72, 3, SAEMO 21, 38.

46 Epistola 72a, 15, SAEMO 21, 58.

47 Epistola 73, 17-18, SAEMO 21, 74. 
usiłował niepokoić Kościół mediolański przez godne potępienia zgromadzenia: raz przed bramą synagogi, to znów po domach arian, knując tajemne plany i zbierając swoich [zwolenników], a ponieważ nie mógł otwarcie występować na ich zgromadzeniach, szkodził pouczając ich i kształcąc w jaki sposób mogą zakłócać pokój Kościoła. A z ich wściekłości czerpał nadzieję, że będzie mógł pozyskać dla siebie ich popleczników i stronników" 48 .

6. Kto nie ma nadziei. Mówiąc o nadziei, czasem św. Ambroży pokazuje, kto tej nadziei nie ma. I tak w liście do biskupa Konstancjusza, zachęcając go do częstego i gorliwego głoszenia kazań, pisze odnośnie tego właśnie nauczania:

„,Jest ono bowiem przepaską, która zazwyczaj przewiązuje rany duchowe; jeśli ktoś ją odrzuci, wychodzi na jaw, że nie ma nadziei na jego zbawienie. I dlatego względem tych, którzy są dręczeni ciężkim poranieniem, używaj oliwy słów, aby nią złagodzić zatwardziałość ducha, przyłóż okład, dołącz przepaskę zbawiennego nakazu, abyś w żaden sposób przez twoją opieszałość i osłabioną gorliwość, gdy chodzi o wiarę i zachowanie dyscypliny, nie pozwolił zginąć niestałym i chwiejnym" 49 .

Pisząc o sposobie życia i nadzwyczajnych czynach Samsona, wspomina też o jego narodzeniu, zapowiedzianym przez anioła, który ukazał się jego rodzicom:

„,Wkrótce potwierdził nimi prawdziwość Bożej zapowiedzi, gdyż nie bez powodu poprzedziła go tak wielka łaska, że zstąpił anioł, który nie majacym nadziei [na potomstwo] rodzicom zwiastował jego narodzenie, przyszłe rządy i to, że będzie obroną swoich [rodaków]: bo już od długiego czasu byli udręczeni pod ciężkim panowaniem Filistynów (por. Sdz 13, 3-5) ${ }^{\text {,50. }}$.

Podobnie nawiązuje do dramatycznej sytuacji Żydów obleganych przez wodza asyryjskiego Holofernesa w Betulii, w tekście wychwalającym moc, która kryje się w słabości (por. 1Kor 1,27) kobiety silnej wiarą, modlitwą i umartwieniem:

„Judyta, żadną miarą nie skuszona hulaszczą ucztą Holofernesa, jedynie za pomocą trzeźwości odniosła triumf, którego nie było nadziei odnieść siłą męskich ramion, uwolniła ojczyznę z oblężenia"s1.

7. Zwyczajne nadzieje. Kilkakrotnie św. Ambroży używa też wyrażenia „mieć nadzieję” w znaczeniu bardzo zwyczajnym, potocznym. Czasem czyni to dla ukazania kontrastu z osobami, które posiadają tę ,,wielką nadzieję" na

48 Epistola 5*, 3, SAEMO 21, 196.

49 Epistola 36, 7, SAEMO 20, 26, BOK 20, 9.

50 Epistola 62, 10, SAEMO 20, 152, BOK 20, 102-103.

51 Epistola 14*, 29, SAEMO 21, 278. 
zbawienie. Kiedy indziej natomiast po prostu mówi o tych, którzy mają nadzieję, że coś otrzymają lub że coś się stanie. Pisząc do Teodozjusza w bardzo delikatnej kwestii Callinicum, gdzie została spalona synagoga przez chrześcijan, być może zachęconych przez samego biskupa, św. Ambroży nakłania cesarza do odwołania surowych decyzji przez wzgląd na Chrystusa, o którego łaskawość powinien zabiegać dla siebie i swoich synów:

„Masz tych, dla których powinieneś jeszcze prosić o łaskawość Pana względem cesarstwa rzymskiego, masz tych, w których powinieneś pokładać nadzieję bardziej niż w sobie: w tych moich słowach niech poruszy cię ich szczęście, ich zbawienie" ${ }^{n 2}$.

W swej interwencji przeciw zleceniu świeckim przez cesarza Walentyniana II sądzenia spraw dotyczących Kościoła nasz Biskup przytacza taką argumentację:

„Nie pozwala się tego powiedzieć biskupom, a pozwoli się świeckim? I będzie sądził w sprawach wiary ten, kto albo ma nadzieję pozyskać życzliwość albo boi się obrazić?" $" 53$.

Wspominając w liście do Sewera, biskupa Neapolu, powrót pewnego kapłana Jakuba z dalekiej Zatoki Perskiej, pisze, iż w Kampanii „spodziewał się znaleźć spokój" ${ }^{54}$ po długotrwałych trudach apostolskich.

Na Synodzie plenarnym w Kapui w 391 r. zebrani biskupi starali się zakończyć wreszcie długotrwałą schizmę w Antiochii, która zakłócała harmonię w Kościele. Misję pośredniczenia w tym pojednaniu zlecono biskupowi Aleksandrii Teofilowi. Kiedy okazało się, że jego misja nie przyniosła oczekiwanego skutku, św. Ambroży, także w imieniu innych biskupów, pisze do niego z pewną dozą goryczy:

„Gdy przeto my mieliśmy nadzieje, że za pomocą tych jak najbardziej słusznych postanowień Synodu zostało znalezione lekarstwo i położony kres niezgodzie, twoja świątobliwość pisze, że nasz brat Flawian znowu uciekł się do pomocy próśb i do pośrednictwa rozporządzeń cesarskich. Na próżno więc został włożony wysiłek tylu biskupów?" 55 .

Po śmierci biskupa Tesalonik Acholiusza w 383 r. jego następcą wybrano jego ucznia i współpracownika Anyzjusza. Św. Ambroży korzysta z okazji i wysyła mu list, zawierający na początku wyrazy współczucia z powodu śmierci duchowego ojca, a następnie radość z jego wyboru na ten urząd:

„Już od dawna cię znam - nawet jeśli teraz po raz pierwszy czytam [list od ciebie] i wiadomo mi o twoich zasługach, choć jeszcze nie widziałem cię na oczy. Ubole-

52 Epistola 74, 31, SAEMO 21, 104.

53 Epistola 75, 11, SAEMO 21, 110.

54 Epistola 49, 1, SAEMO 20, 78, BOK 20, 41.

55 Epistola 70, 3, SAEMO 21, 30-32. 
wam zatem, że zdarzyło się tamto [nieszczęście], lecz cieszę się z takiego następstwa; gdyż, chociaż życzyłem sobie, aby się to nie wydarzyło za mojego życia, jednakże miałem nadzieję, że po odejściu tego świętego męża właśnie to jedno nastąpi. Znamy cię zatem, dawniej jako ucznia świętej pamięci Acholiusza, a teraz jego następcę i dziedzica, zarówno jego czci jak też i prestiżu. Wielka to zasługa, bracie. Cieszę się z powodu ciebie, że ani przez chwilę nie było wątpliwości co do następcy tak wielkiego męża"56.

Usprawiedliwiając swoją czasową nieobecność w Mediolanie w 394 r., kiedy do miasta wtargnął uzurpator Eugeniusz, św. Ambroży pisze do cesarza Teodozjusza:

„Myślałeś, że na długo przebywałem poza miastem Mediolanem. Lecz ja nie byłem aż tak nieświadomy twego męstwa albo twoich zasług, żebym nie spodziewał się, iż twoja Pobożność będzie wspierana niebiańską pomocą, dzięki której uwolnisz cesarstwo Rzymskie od dzikości barbarzyńskiego zbójcy i od władania niegodnego uzurpatora" ${ }^{17}$.

W dramatycznej walce o uratowanie kościołów katolickich w Mediolanie przed zabraniem ich przez cesarza, który zamierzał oddać je arianom, nasz Biskup był gotów na wszystko, łącznie z oddaniem życia. Zdecydowanie używa wszystkich środków, jakie miał do dyspozycji, aby nie oddać kościołów, ale też nie dopuścić do krwawych starć. W liście do cesarza Walentyniana II pisze:

„Oby też wyraźnie było dla mnie widoczne, że kościół absolutnie nie zostanie
wydany arianom! Dobrowolnie poddałbym się sądowi twojej łaskawości. Lecz
jeżeli ja tylko robię hałas, to dlaczego został wydany rozkaz, by zostały zajęte
także wszystkie inne kościoły? Dałby Bóg, aby zaręczono nam, że nikt nie będzie
niepokoił kościołów! Mam nadzieję, że co do mnie zostanie wydany taki wyrok,
jaki wyda się słuszny "s8.

A w załączonej do tego listu mowie przeciw Auksencjuszowi zawarta jest też wzmianka o tym, że mediolański Pasterz liczył się z możliwością swego męczeństwa, podczas gdy zaledwie starano się go pogróżkami nakłonić do opuszczenia miasta:

„Nikt mnie nie zatrzymał, aczkolwiek mieli ochotę mnie wypędzić, jak później to wyjawili, mówiąc: «Wyjdź z miasta i idź dokąd chcesz». Spodziewałem się, przyznaję, czegoś poważnego: albo [śmierci od] miecza dla imienia Chrystusa albo pożaru, tymczasem oni zamiast cierpień ofiarowali mi rozkosze; lecz atleta Chrystusa żąda nie rozkoszy, lecz swoich cierpień" ${ }^{59}$.

\footnotetext{
56 Epistola 52, 1, SAEMO 20, 92, BOK 20, 50.

5 Epistola 2*, 1, SAEMO 21, 190.

58 Epistola 75, 19, SAEMO 21, 114.

59 Epistola 75a, 15, SAEMO 21, 122.
} 
Już bardzo pobieżne spojrzenie na przytoczone teksty pozwala nam stwierdzić, że św. Ambroży w sposób głęboki żył nadzieją chrześcijańską, ukazywał ją i zalecał innym w swoich pismach. Nie należy przy tym wcale myśleć, że dominuje u niego negatywne nauczanie o nadziei, czyli ostrzeganie przed fałszywym czy spłyconym jej rozumieniem. Owszem, i ten wątek jest obecny, ale jest on tylko tłem, na którym przedstawia swoją głęboką i pełną wiary, pozytywną wizję nadziei dóbr wiecznych.

Ogromna większość tekstów mówi bowiem o nadziei w sensie teologicznym, jako o cnocie ściśle związanej z wiarą i miłością, oraz w znaczeniu eschatologicznym, jako oczekiwaniu wiecznego życia w Królestwie Bożym. Nawet te wypowiedzi, które pozornie ukazują ludzi nie mających nadziei albo żywiących złudne nadzieje, często są w kontekście potwierdzeniem i wskazówką, że jedyną prawdziwą nadzieją świata jest Chrystus.

Zasługuje na podkreślenie fakt, iż wiele z wypowiedzi naszego Autora odnosi się do ludzi sprawiedliwych znoszących różne cierpienia, prześladowania i udręki, dla których ostoją i źródłem sił w utrapieniach jest właśnie ich nadzieja. Podobnie zresztą była ona oparciem dla niego samego w różnych zmaganiach jego niełatwej biskupiej posługi w bardzo burzliwych czasach. Niech zatem słowo i przykład tego świętego Pasterza będzie i dla nas zachętą! Podobnie jak on, nieśmy ludziom nadzieję - zgodnie z tym, co Jan Paweł II zalecał na początku 2001 roku:

„Idźmy naprzód z nadzieją! Nowe tysiąclecie otwiera się przed Kościołem niczym rozległy ocean, na który mamy wypłynąć licząc na pomoc Chrystusa. [...] Czyż nie po to właśnie obchodziliśmy Rok Jubileuszowy, aby na nowo zaczerpnąé z tego żywego źródła naszej nadziei? Dzisiaj Chrystus, którego kontemplujemy i miłujemy, znów wzywa nas, byśmy wyruszyli w drogę: «Idźcie więc i nauczajcie wszystkie narody, udzielając im chrztu w imię Ojca i Syna, i Ducha Świętego» (Mt 28, 19). Ten misyjny mandat wprowadza nas w trzecie tysiąclecie, wzywając nas, byśmy naśladowali entuzjazm pierwszych chrześcijan: możemy liczyć na moc tego samego Ducha, który został wylany w dniu Pięćdziesiątnicy, a dzisiaj przynagla nas, abyśmy wyruszyli w dalszą drogę pokrzepieni nadzieją, «która zawieść nie może»" (Rz 5, 5)" "60.

${ }^{60}$ Epistula Apostolica „Novo millennio ineunte” 58, wyd. „Znak”: Listy Apostolskie Ojca Świętego Jana Pawła 1I, Kraków 2007, 673-674. 


\section{IL CONCETTO DELLA SPERANZA \\ NELLE LETTERE DI S. AMBROGIO DI MILANO}

(Riassunto)

Poiché recentemente il Papa Benedetto XVI ci ha voluto ricordare la grande attualità della speranza con la sua lettera enciclica Spe salvi, rievocando anche la testimonianza dei cristiani e pastori dei tempi antichi, mi è venuta l'idea di esaminare sotto l'aspetto del termine della speranza le Lettere di S. Ambrogio di Milano.

Nella ricerca è apparsa la ricchezza del suo insegnamento a questo riguardo. Il primo e più frequente senso del termine ,speranza” è proprio quello profondamente cristiano ed escatologico. Specialmente nei commenti alle Lettere di San Paolo il nostro Autore dimostra una vicinanza del pensiero con quello da cui inizia il Papa la sua enciclica: „Nella speranza siamo stati salvati”.

Nelle riflessioni sulla speranza S. Ambrogio, sull'esempio dell'Apostolo Paolo, mette in stretto collegamento con essa le altre virtù, specialmente la fede e la carità. Contemporaneamente avverte che la contrastano i vizi, i quali deviano i nostri desideri dal Signore e dal suo premio eterno verso i beni materiali e temporali.

Un ampio spazio nell'insegnamento sulla speranza del nostro Vescovo occupa la relazione tra questa e le sofferenze e persecuzioni, subite dai giusti per la causa del Signore e della fede. Egli richiama qui l'esempio di tanti profeti e giusti biblici come anche i fedeli Pastori della Chiesa, esortando i suoi fedeli ad imitarli. Non per ultimo offre anche il proprio esempio, quando nei momenti drammatici del suo episcopato non esita di manifestare la sua prontezza al martirio per non cedere alle ingiuste pretese degli ariani o degli imperatori, i quali minacciavano il bene spirituale del gregge a lui affidato.

La visione della speranza di S. Ambrogio è molto cristocentrica, come del resto tutta la sua teologia. Infatti, proprio Cristo è la sorgente e garanzia della nostra vera speranza. In questo contesto si pone un'espressione che si può dire il frutto maturo dell'insegnamento del nostro Dottore sulla speranza: Il fine della nostra speranza è il suo amore (Epistola 16, 3). 